\title{
Photoalteration of macrophyte-derived chromophoric dissolved organic matter induces growth of single bacterial populations in a coastal lagoon
}

\author{
Claudia PICCINI, ${ }^{*}$ Daniel CONDE, ${ }^{2}$ Jakob PERNTHALER,${ }^{3}$ Ruben SOMMARUGA ${ }^{4}$ \\ ${ }^{1}$ Laboratorio de Microbiología, Instituto de Investigaciones Biológicas Clemente Estable, av. Italia 3318, 11600 Montevideo; ${ }^{2}$ Sección \\ Limnología, Departamento de Ecología, Universidad de la República, Iguá 4225, 11400 Montevideo, Uruguay; ${ }^{3}$ Limnological Station, \\ Institute of Plant Biology, University of Zurich, Seestrasse 187, CH-8802 Kilchberg, Switzerland; ${ }^{4}$ Laboratory of Aquatic Photobiology \\ and Plankton Ecology, Institute of Ecology, University of Innsbruck, Technikerstrasse 25, 6020 Innsbruck, Austria \\ *Corresponding author: claudia.piccini@gmail.com
}

\begin{abstract}
Photochemical degradation is an important process involved in the decay of macrophytes, but little is known on the response of heterotrophic bacteria to the chromophoric dissolved organic matter (CDOM) derived from different plant species. Here, we assessed the effect of photoaltered CDOM derived from Schoenoplectus californicus and Ruppia maritima on the composition and production of a bacterial community from a productive subtropical coastal lagoon. Chromophoric dissolved organic matter from plants extracts was characterised by optical methods before and after exposure to natural full solar radiation. Afterwards, bacteria from the lagoon were added and incubated in these extracts for $5 \mathrm{~h}$. We found that CDOM from the plant extracts underwent photoalteration after exposure to natural solar radiation, inducing shifts in the original bacterial community composition. In both macrophyte extracts, the bacterial community significantly changed and became dominated by two populations with distinctive morphology. The main enriched bacteria in both plant extracts were large filaments that made up to $99 \%$ of the community biovolume. In the R. maritima extract, another type of enriched bacteria was detected, consisting of large rods. $16 \mathrm{~S} \mathrm{rDNA} \mathrm{sequencing} \mathrm{showed} \mathrm{that} \mathrm{the} \mathrm{enriched} \mathrm{bacterial} \mathrm{populations} \mathrm{be-}$ longed to Exiguobacterium sp. (filaments) and Acinetobacter sp. (rods). Morphotype identities were confirmed by fluorescence in situ hybridisation using specific probes targeting those taxa. Our results suggest that solar-induced photoalteration of plant material in this coastal lagoon results in the growth of opportunistic bacterial taxa.
\end{abstract}

Key words: chromophoric dissolved organic matter, macrophytes, Exiguobacterium, Acinetobacter, coastal lagoon.

Received: April 2013. Accepted: June 2013.

\section{INTRODUCTION}

Dissolved organic matter (DOM) has different sources in aquatic ecosystems, e.g. allochthonous, from soil runoff, or autochthonous, from exudation and decomposition of primary producers. The relative contribution of DOM derived from each source will depend on the biological and physicochemical characteristics of the water body and its catchment. In particular, the hydrology of the systems is an important factor conditioning the source and availability of DOM. Allochthonous DOM differs from autochthonous in several optical (McKnight et al., 1994) and chemical characteristics (Benner, 2002). Allochthonous organic matter is usually more refractory to bacterial degradation (del Giorgio and Davis, 2003), probably due to the high proportion of chromophoric DOM (CDOM) consisting of humic substances. Differences in chemical composition of CDOM are thought to influence the structure of natural bacterial assemblages (Crump et al., 2003). From several studies assessing changes in the structure and activity of the bacterial community in relation to DOM (Cottrell and Kirchman, 2000; Elifantz et al., 2005; Alonso et al., 2009), it seems that even considering large taxonomic groups, bacteria differ in their capacity to use specific dissolved organic compounds. Therefore, qualitative changes in the DOM source might trigger a shift in bacterial community structure and activity.

The CDOM concentration in freshwater is usually higher than in marine water, owing to the high primary productivity of macrophytes and larger influence of the terrestrial catchment (Wetzel, 1992). Plant-derived DOM can enter ecosystems via photosynthates excretion or by plant lixiviation (Mann and Wetzel, 1996), which is considered a main source of DOM in many aquatic systems (Wetzel, 1992). In coastal lagoons, macrophytes can cover large littoral extensions; as a consequence, CDOM from plantdecaying material is one of the main carbon and nutrient source to these ecosystems (Conde et al., 2000). During the decay process, photochemical degradation is important because small molecular weight substrates are made available for microbial growth (Wetzel, 2003). However, little is known on how photoaltered CDOM from different macrophyte species affects the bacterial community.

Alonso et al. (2013) recently showed that the addition of allochthonous carbon sources induces pronounced 
shifts in the bacterial assemblage of a shallow coastal lagoon, while the amendment of nutrients such as nitrogen $(\mathrm{N})$ or phosphorus $(\mathrm{P})$ does not have a significant effect on it. These results suggest that bacterioplankton growth in this type of aquatic ecosystem would be predominantly limited by carbon and that this limitation would be more or less intense depending on the hydrology of the system (Alonso et al., 2013). The reason for this limitation is probably that during some phases of the lagoon hydrology, the main source of organic carbon for bacteria is macrophytes-derived DOM, which due to their chemical composition cannot be readily incorporated by bacteria for growth. In fact, we have previously shown that photoalteration of CDOM stimulates bacterioplankton growth and induces changes in community composition (Piccini et al., 2009). One of the current hypotheses about the possible carbon sources for bacterioplankton in this system is that UV-induced photoalteration of macrophytes-derived DOM increases carbon availability to sustain bacterial growth. Further, we expect that the photoproducts derived from different decaying macrophytes species will differ in their overall effect on the bacterial assemblage. Here, we determined whether photoaltered CDOM derived from two macrophytes species of a coastal lagoon, namely the California bulrush Schoenoplectus californicus (C.A. Mey.) Palla and the widgeongrass Ruppia maritima L. (Rodríguez-Gallego et al., 2010), is a relevant process shaping the heterotrophic bacterial community.

\section{METHODS}

\section{Preparation of dissolved organic matter sources and experimental setup}

To assess the effect of solar radiation on the different DOM sources, an in situ experiment was done in January during the austral summer in the freshwater zone of a brackish coastal lagoon (Laguna de Rocha, Uruguay, 34 ${ }^{\circ} 837^{\prime} \mathrm{S}$, $54^{\circ} 817^{\prime} \mathrm{W}$ ) (Conde et al., 2000). Two different classes of DOM consisting of extracts from $S$. californicus (submerged stems) (SCD) and R. maritima (whole plants) (RMD) were selected. Samples were processed in sterile Milli-Q water (Millipore, Billerica, MA, USA) by homogenising the material for $10 \mathrm{~min}$ at room temperature using a Stomacher lab blender (Seward, Worthing, UK). Homogenates were centrifuged at $2000 \mathrm{xg}$ and the supernatants were filtered through $0.2 \mu \mathrm{m}$ polycarbonate filters (Millipore), previously soaked overnight in $10 \% \mathrm{HCl}$ and rinsed with 20 $\mathrm{mL}$ of Milli-Q water. Absence of bacterial contamination in the resulting filtrate was checked by epifluorescence microscopy and 4',6-diamino-2-phenylindole (DAPI) counts on $0.2 \mu \mathrm{m}$ filters (Porter and Feig, 1980).

The DOM extracts were filled into $100 \mathrm{~mL}$ spherical quartz bottles in triplicate (Piccini et al., 2009), and exposed to natural solar radiation for two days ( $8 \mathrm{~h}$ of effec- tive solar exposure each day) in a circulating water bath at in situ temperature $\left(24.5^{\circ} \mathrm{C}\right)$, where they were completely submerged and manually rotated each hour. Optical properties of the filtrates were determined before (initial) and after exposure to solar radiation (16 h). In addition, dissolved organic carbon (DOC) concentration was measured before exposure of the DOM extracts.

Solar UV irradiance during exposure was measured in situ with an International Light radiometer (IL-1400A; International Light Technologies Inc., Peabody, MA, USA) consisting of the broadband SUL033/W (UV-A) and SUL240/W (UV-B) sensors. Incident radiation for UV-B and UV-A was integrated for the total exposure and corresponded to $5.2 \mathrm{~J}$ and $237.4 \mathrm{~J} \mathrm{~cm}^{-2}$, respectively.

To assess the response of the in situ bacterial assemblage, each quartz bottle was inoculated with $10 \mathrm{~mL}$ of water collected from the freshwater zone of the lagoon to obtain a 1:10 dilution of the original lagoon community (T0) and thus to minimise the effect of predators. All quartz bottles were then incubated for $5 \mathrm{~h}$ under natural solar radiation. A set of 3 quartz bottles was used as control, which were filled with the natural microbial community, but without plant extracts. Incident radiation for UV-B and UVA during this incubation corresponded to $2.1 \mathrm{~J}$ and $25 \mathrm{~J}$ $\mathrm{cm}^{-2}$, respectively. Measurements of CDOM optical characteristics were repeated after the $5 \mathrm{~h}$ incubation.

\section{Optical characterisation of chromophoric dissolved organic matter}

For the analysis of DOC concentration and optical properties of CDOM, samples were filtered on the same day (within $6 \mathrm{~h}$ ) through $0.2 \mu \mathrm{m}$ polycarbonate filters (Millipore), previously soaked overnight in $10 \% \mathrm{HCl}$ and rinsed with $20 \mathrm{~mL}$ of Milli-Q water (Millipore). Filtered water was stored in precombusted $\left(500^{\circ} \mathrm{C}, 1 \mathrm{~h}\right)$ glass bottles (Tefloncapped) and kept in the dark at $-20^{\circ} \mathrm{C}$ for DOC analysis or at $4^{\circ} \mathrm{C}$ for the optical characterisation of CDOM (absorption and fluorescence). The concentration of DOC (as non purgeable organic carbon) was measured using a high temperature catalytic oxidation method (Shimadzu TOC analyser model 5000; Shimadzu, Kyoto, Japan). Calibration of the instrument was done with potassium hydrogen phthalate (four points calibration curve). A consensus reference material (CRM) for DOC [batch 5 FS-2005:0.57 $\mathrm{mg} \mathrm{C} \mathrm{L}^{-1}$ provided by the Rosenstiel School of Marine and Atmospheric Science/Division of Marine and Atmospheric Chemistry (RSMAS/MAC), University of Miami] was run in parallel. Results differed from the CRM given value by $5 \%$ and the coefficient of variation was better than $2 \%$.

Chromophoric dissolved organic matter absorbance was measured at room temperature in a double-beam spectrophotometer (Shimadzu UV1603; Shimadzu) between 280 and $750 \mathrm{~nm}$ using acid-cleaned $5 \mathrm{~cm}$ fused silica cuvettes (Suprasil ${ }^{\circledR}$ I) previously rinsed with Milli-Q 
water (Millipore) and twice with the filtered sample. Milli-Q water (Millipore) of low DOC concentration $\left(0.05 \mathrm{mg} \mathrm{L}^{-1}\right)$ was used as a reference. Absorption coefficients $(a)$ were calculated as: $a=2.303 \mathrm{D} / \mathrm{L}$, where $\mathrm{D}$ is absorbance and $\mathrm{L}$ is the pathlength of the cuvette in expressed in $\mathrm{m}$. Correction for the scattering caused by particles was done by subtracting the absorbance value at $690 \mathrm{~nm}$. For comparative purposes, we used the absorption value at $320 \mathrm{~nm}\left(a_{320}\right)$, which is sensitive to changes caused by both UV-B and UV-A radiation. The CDOM absorption at $320 \mathrm{~nm}$ was also normalised to the DOC concentration $\left(a^{*}{ }_{320}\right)$. Spectral slope $(S)$ was calculated for each treatment before and after exposure for the ranges 275-295 nm (UV-B) and 350-400 nm (UV-A) (Helms et al., 2008). In addition, the ratio of both calculated slopes $\left(S_{\mathrm{R}}\right)$ was calculated to trace changes in CDOM related to photobleaching (Helms et al., 2008).

To infer changes in the dominant molecular size of $\mathrm{CDOM}$, the ratio between the absorption coefficients at 250 and $365 \mathrm{~nm}\left(\mathrm{a}_{250}: \mathrm{a}_{365}\right)$ was used, where high ratios indicate a high proportion of small molecules and low ratios a high proportion of large molecules (De Haan, 1993). Samples for fluorescence measurements were filtered as for DOC and the filtrates were collected in $20 \mathrm{~mL}$ vials (acid washed, rinsed with Milli-Q water, and pre-combusted as above). Fluorescence ( $\mathrm{Fl}$ ) was measured at room temperature in an AMINCO Bowman Serie 2 spectrofluorometer (excitation at $355 \mathrm{~nm}$, emission at 450, slit width of $5 \mathrm{~nm}$ ) using a $1 \mathrm{~cm}$ quartz cuvette, prerinsed with MilliQ water (Millipore) and with the filtered sample. Fluorescence standardisation was done by normalising the signal of the sample to the fluorescence of a solution of quinine sulfate $1 \mathrm{mg} \mathrm{L}^{-1}$ in $1 \mathrm{~N} \mathrm{H}_{2} \mathrm{SO}_{4}$ defined as 1 quinine sulfate unit (QSU). Fluorescence was linear between 0.05 and 10 $\mathrm{mg} \mathrm{L}^{-1}$ of quinine sulfate. To account for potential instrumental drift, separate quinine sulfate spectra were acquired on each day of measurement.

\section{Bacterial abundance and biovolume}

Samples $(3 \mathrm{~mL})$ were taken from each treatment bottle and fixed with $1 \%$ paraformaldehyde-PBS $\mathrm{pH}$ 7.2. On the same day, samples were filtered through polycarbonate $0.2 \mu \mathrm{m}$ pore diameter filters (Millipore). Bacterial abundance (excluding filaments and large rods) was determined by epifluorescence microscopy and DAPI staining (final concentration $1 \mu \mathrm{g} \mathrm{mL}^{-1}$ ) as previously described (Porter and Feig, 1980). The biovolume of filaments and large rods was determined at the beginning (T0) and the end of bacterial incubation $(5 \mathrm{~h})$ using the image analysis process and algorithms described by Massana et al. (1997). The cumulative length of filaments $\left(\mu \mathrm{m} \mathrm{mL}^{-1}\right)$ in each sample and the corresponding biovolume were calculated according to Nedoma et al. (2001). Images were taken at 8 bit, resolution $1040 \times 1388$ pixels with a $\times 40$ ma- gnification resulting in a pixel length of $\sim 0.466 \mu \mathrm{m}$. Image analyses and measurements of cells dimensions were done using $\mathrm{J}$ software (NIH, Bethesda, MD, USA).

\section{Bacterial carbon production}

Bulk bacterial activity was estimated from the incorporation of $\left[{ }^{3} \mathrm{H}\right]$-L-leucine (Amersham, Little Chalfont, UK) into bacterial biomass (Simon and Azam, 1989). Samples were taken from each of the triplicates at the initial time (T0) and at final time (5 h). Radiolabelled leucine (specific activity $63 \mathrm{Ci} \mathrm{mmol}^{-1}$ ) was added at saturating concentrations (20 nM) (Piccini et al., 2009) to three subsamples and to one formaldehyde-killed control (3\% final concentration) from each water treatment. These sub-samples were incubated in a water bath in the dark at in situ temperature $\left(25^{\circ} \mathrm{C}\right)$ for $1 \mathrm{~h}$ and then fixed with formaldehyde ( $3 \%$ final concentration). Macromolecule extraction was done with ice-cold trichloroacetic acid (TCA) (5\% $\mathrm{w} / \mathrm{v})$ and ice-cold ethanol $(80 \% \mathrm{v} / \mathrm{v})$ according to Simon and Azam (1989). Measurements of [ $\left.{ }^{3} \mathrm{H}\right]$-L-leucine incorporation were done in a Beckman LS5000TD liquid scintillation counter (Beckman, Fullerton, CA, USA). Values were corrected for quenching (external standard method) and by subtraction of counts from the controls. Conversion of leucine incorporation to bacterial protein and carbon production (BCP) was done using the conversion factors described by Simon and Azam (1989).

\section{Polymerase chain reaction amplification, cloning, and sequencing of 16S rRNA genes}

16S rRNA gene clone libraries were constructed from fixed and filtered samples obtained from SCD and RMD incubations as described for bacterial abundance. Pieces of filter of approximately $6 \mathrm{~mm}^{2}$ were cut out and used directly as a template for amplification by polymerase chain reaction (PCR) without previous DNA extraction (Kirchman et al., 2001). Polymerase chain reaction amplification with the general bacterial primers GM3F and GM4R (Muyzer et al., 1995) was done with a Mastercycler (Eppendorf, Hamburg, Germany) using the following conditions: an initial denaturation step of $5 \mathrm{~min}$ at $94^{\circ} \mathrm{C}, 1 \mathrm{~min}$ of denaturation at $94^{\circ} \mathrm{C}, 1.5 \mathrm{~min}$ of annealing at $48^{\circ} \mathrm{C}$, and $2 \mathrm{~min}$ of primer extension at $72^{\circ} \mathrm{C}$. This cycle was repeated 30 times, followed by a final step of $2 \mathrm{~min}$ at $72^{\circ} \mathrm{C}$. The PCR products were checked by agarose $(1 \%$, wt $/ \mathrm{vol})$ gel electrophoresis and the amplified 16S rRNA gene fragments were purified with a QIAquick PCR purification kit (QIAGEN, Hilden, Germany). The purified amplicons were inserted into the pGEM vector (PGEM-T cloning kit; Promega, Fitchburg, WI, USA) and cloned into competent Escherichia coli cells delivered with the kit as described by the manufacturer. White clones were picked and plasmids were extracted with a QIAprep spin miniprep kit (QIAGEN) 
according to the manufacturer's specifications. Ninety-six clones from each library were screened for correctly sized inserts by PCR using the vector primers (M13F and M13R) and further agarose gel electrophoresis of the amplicons $(1 \%)$, and proved to be positive. Plasmids partial sequences were obtained from these positive clones using the primer M13F on an ABI PRISM 3100 genetic analyser (Applied Biosystems, Foster City, CA, USA). After analysing the partial sequences, 48 clones from each library (SCD and RMD) were selected for complete sequencing of the $16 \mathrm{~S}$ rRNA gene using the primers M13R and GM1. Sequences were assembled from three partial sequences using the software Sequencher (Gene Codes, Ann Arbor, MI, USA). All sequences were subsequently analysed by BLAST (Altschul et al., 1990) to identify their closest relatives and to establish tentative phylogenetic affiliations. Phylogenetic analyses were performed using ARB software (Ludwig et al., 2004). For the reconstruction of a phylogenetic tree depicting the affiliations of newly obtained sequences, only nearly complete $16 \mathrm{~S}$ rRNA sequences were considered. Maximum-parsimony, neighbour-joining, and maximumlikelihood analyses were performed. The branching patterns of the resulting trees were compared and a consensus tree was constructed that showed bifurcations only if branchings were stable in the majority of analyses. Multifurcations were introduced if tree topology could not be unambiguously resolved.

\section{Double fluorescence in situ hybridisation}

After sequencing of clones from SCD and RMD treatments, a search for probes targeting the identified bacterial groups was conducted in the probeBase website. Selected probes were used in a double FISH, combining CARD and monolabeled probes according to the protocol described by Pernthaler et al. (2004). Filters used for double FISH were the same as for bacterial abundance determination and clone libraries construction. Briefly, a first hybridisation using the peroxidase-conjugated probe LGC354A (Meier et al., 1999) for low guanine-cytosine (GC) content Grampositive bacteria was done including the catalysed reporter deposition step, but the hybridised filter pieces were not counterstained with DAPI. Instead, they were incubated for $20 \mathrm{~min}$ at room temperature in $0.01 \mathrm{M} \mathrm{HCl}$ to inactivate the horseradish peroxidase and then a second hybridisation was run using the monolabeled S-G-Acin-0652-a-A-18 probe (Oerther et al., 1998) for Acinetobacter spp. conjugated to Cy3. Formamide concentrations in the hybridisation buffers were $55 \%$ for LGC354A and $40 \%$ in the case of S-G-Acin0652-a-A-18 probe.

\section{Statistical analyses}

Unpaired t-tests were used to test for significant differences in CDOM optical parameters, bacterial abundance, and bacterial biomass at the beginning and the end of the experiments. The comparison of the effect of treatments and time on BCP was done with a two-way ANOVA and Bonferroni post-hoc test. For all parameters, the average values were calculated from the three replicates in each treatment. Differences were considered significant when $\mathrm{P}<0.05$. All statistical analyses were run using GraphPad Prism version 5.0 for Mac OS X, GraphPad Software (GraphPad, San Diego, CA, USA).

\section{RESULTS}

\section{Photoalteration of chromophoric dissolved organic matter}

The absorption coefficient at $320 \mathrm{~nm}\left(a_{320}\right)$ of the macrophyte extracts decreased after $16 \mathrm{~h}$ exposure (unpaired t-test, $\mathrm{P}<0.01$ ) (Tab. 1). Similarly, the spectral slopes and the $S_{\mathrm{R}}$ for each treatment increased in the UV-B range after irradiation of both plant extracts (unpaired t-test, $\mathrm{P}<0.01)$. The $\mathrm{a}_{250}: \mathrm{a}_{365}$ ratios from SCD before exposure to solar radiation were higher than the observed for RMD (Tab. 1). After exposure to solar radiation, the $\mathrm{a}_{250}: \mathrm{a}_{365}$ ratio increased in both extracts. Thus, the relative molecular size of CDOM decreased by ca. 10\% in SCD (unpaired t-test, $\mathrm{P}<0.05$ ) and by ca. 17\% in RMD (unpaired t-test, $\mathrm{P}<0.05$ ) extract (Tab. 1). No further significant change in CDOM optical characteristics was observed after the $5 \mathrm{~h}$ incubation (data not shown).

\section{Bacterial community response}

When the bacterial community was analysed in both plant extracts after $5 \mathrm{~h}$ incubation, changes in cell size distribution were detected, namely, the mean cell volume was significantly larger (unpaired t-test, $\mathrm{P}<0.05$ ) than that of the original natural bacterial community (Figs. 1 and 2). In the bacterial community incubated without plant extracts, the mean cell volume was the same as in T0 (data not shown). In SCD, the bacterial community was dominated by large filaments of ca. $100 \mu \mathrm{m}$ length and ca. $5 \mu \mathrm{m}$ wide, with a mean volume of $6.19 \pm 2.72 \times 10^{6} \mu \mathrm{m}^{3} \mathrm{~mL}^{-1}$, corresponding to $97.7 \%$ of the whole community biovolume (Fig. 2C). Filaments were also present in RMD, where they comprised $90.6 \%$ of the whole community biovolume. In addition, in the RMD treatment large rods with an average cellular volume of $6.5 \pm 2.37 \mu \mathrm{m}^{3}$ and representing $8.7 \%$ of the bacterial biovolume were found (Fig. 2D). These rods were also found in the SCD treatment, but at lower abundance. Both enriched bacterial populations (large filaments and rods) were undetectable at the initial time (Fig. 2A and 2B). Furthermore, the abundance of bacteria that were not large rods nor filaments present in both treatments did not show significant changes during incubation (unpaired $t$-test, $\mathrm{P}>0.05$ ) (Fig. 3), suggesting that the newly developed bacterial populations responded to the photoaltered plant-derived DOM, 
whereas the rest of the community did not. When the bulk $\mathrm{BCP}$ was assessed, an increase was observed after $5 \mathrm{~h}$ in both treatments, but it was significant only in the case of the RMD extract (unpaired t-test, $\mathrm{P}<0.05$ ) (Fig. 4).

To identify the dominant bacterial populations, clone libraries of the 16S rRNA gene were constructed from SCD and RMD samples and almost complete (ca. 1500 bp) $16 \mathrm{~S}$ rDNA sequences were obtained from several clones. Pairwise comparison against Genebank database and phylogenetic analyses using ARB (Ludwig et al., 2004) showed that $20.8 \%$ of the clones proved to be positive from SCD treatment and harboured sequences $\geq 99 \%$ identical to several strains of Exiguobacterium acetylicum and 35.4\% to Acinetobacter spp. (Fig. 5A). In contrast, $18.8 \%$ of sequences obtained from positive clones belonging to RMD clone library showed 96 to $99 \%$ identity to Exiguobacterium spp. and $21 \%$ showed $100 \%$ similarity with Acinetobacter sp., being A. bayly the closest described phylotype (Fig. 5B). To confirm the identity of the enriched bacteria, oligonucleotide probes targeting the obtained ribosomal sequences (Acin0659A for Acinetobacter and LGC354A for Exiguobacterium) were applied in FISH assays. Both probes hybridised to the expected bacterial morphotypes (i.e. rods and filaments, respectively). In the case of Acin0659A-hybridised cells, abundance in SCD and RMD treatments were $1.48 \pm 0.34$ and $2.52 \pm 3.03 \times 10^{5}$ cells $\mathrm{mL}^{-1}$, respectively. In RMD, where they were more abundant, Acin0659A-hybridised cells increased from $0.11 \%$ of the total bacterial community at the beginning of the experiment (or in the control) to $>11 \%$ at the end of the incubation (Fig. $5 \mathrm{C}$ ).

\section{DISCUSSION}

In this work, we found that solar radiation caused photobleaching of the macrophyte-derived CDOM as indica- ted by changes in its optical properties $\left(a_{320}, \mathrm{Fl}\right.$, and spectral slopes) (Kirk, 1994; McKnight et al., 2001; Helms et al., 2008). Considering that CDOM is heterogeneous in nature, only a small portion may be chromophoric and thus responsible for photochemical reaction (Osburn et al., 2001). The changes in optical parameters observed for the macrophyte extracts after incubation $\left(a_{320}\right.$, spectral slopes and $S_{\mathrm{R}}$ ) confirmed the photobleaching of CDOM. According to the $\mathrm{a}_{250}: \mathrm{a}_{365}$ ratios measured before incubation, CDOM from SCD extract showed to be more labile than RMD, however, after exposure to solar radiation, these

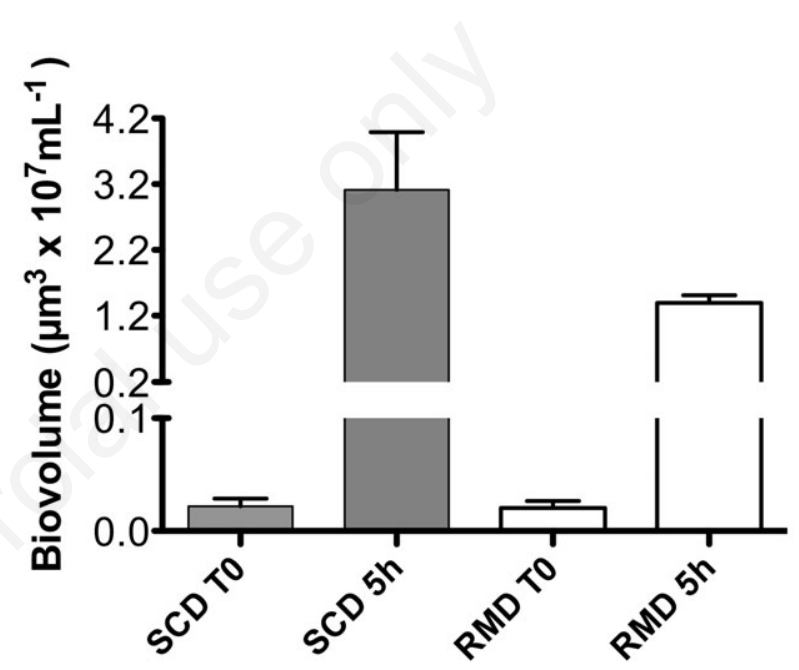

Fig. 1. Average bacterial volumes and standard deviations (in $\mu \mathrm{m}^{3}$ per $\mathrm{mL} \times 10^{7}$ ) calculated at the beginning (T0) and at the end $(5 \mathrm{~h})$ of the incubation in both plant treatments. $\mathrm{SCD}=S$. $c a$ lifornicus dissolved organic matter; $\mathrm{RMD}=R$. maritima dissolved organic matter.

Tab. 1. Water optical characteristics for both plant extracts before and after exposure to solar radiation and initial dissolved organic carbon concentration.

\begin{tabular}{|c|c|c|c|c|}
\hline & \multicolumn{2}{|c|}{ SCD } & \multicolumn{2}{|c|}{ RMD } \\
\hline & Initial (SD) & 16 h (SD) & Initial (SD) & 16 h (SD) \\
\hline $\mathrm{DOC}\left(\mathrm{mg} \mathrm{L}^{-1}\right)$ & 99.80 & ND & 67.90 & ND \\
\hline$a_{320}\left(\mathrm{~m}^{-1}\right)$ & $80.73(0.20)^{*}$ & $51.90(8.98)^{*}$ & $54.88(0.49)^{*}$ & $38.53(4.99)^{*}$ \\
\hline $\mathrm{Fl}\left(\mathrm{mg} \mathrm{L}^{-1}\right)^{\circ}$ & $4.66(0.02)$ & $2.38(0.59)$ & $2.49(0.03)$ & $2.38(0.85)$ \\
\hline$S(275-295 \mathrm{~nm})$ & $0.009(0.001)^{*}$ & $0.015(0.0001)^{*}$ & $0.003(0.00)^{*}$ & $0.010(0.001)^{*}$ \\
\hline$S(350-400 \mathrm{~nm})$ & $0.024(0.00)$ & $0.020(0.001)$ & $0.018(0.001)$ & $0.016(0.002)$ \\
\hline$S_{\mathrm{R}}$ & $0.36(0.00)$ & $0.77(0.002)$ & $0.17(0.001)$ & $0.60(0.005)$ \\
\hline $\mathrm{a}_{250}: \mathrm{a}_{365}$ & $4.87(0.001)^{*}$ & $5.31(0.24)^{*}$ & $2.95(0.01)^{*}$ & $3.47(0.13)^{*}$ \\
\hline
\end{tabular}

$S C D$, dissolved organic matter from $\mathrm{S}$. californicus; $R M D$, dissolved organic matter from $\mathrm{R}$. maritima; $S D$, standard deviation; DOC, dissolved organic carbon; ND, not determined; $a_{320}$, absorption coefficients at $320 \mathrm{~nm} ;$ Fl, fluorescence; S, spectral slopes calculated from the absorption spectra before (initial) and after sunlight exposure $(16 \mathrm{~h}) ; \mathrm{S}_{\mathrm{R}}$, ratio of calculated slopes; $a_{250}: a_{365}$, ratio between the absorption coefficients at 250 and $365 \mathrm{~nm}$. ${ }^{\circ}$ Expressed as quinine sulphate units (QSU), where $1 Q S U=1 \mu \mathrm{g} \mathrm{L}{ }^{-1}$ of quinine sulphate; *significant differences between initial time and after $16 \mathrm{~h}$ incubation within each treatment at $P<0.05$. 
ratios increased in both extracts, indicating that the bioavailability of DOM from the two plant sources was enhanced by exposure to solar radiation and photoalteration. The differences in optical characteristics found between both plants may reflect differences in their chemical composition for these species (Farjalla et al., 2001).

Previous studies have shown that sedimentary organic matter in Laguna de Rocha is mainly derived from the macrophyte community (Conde and Sommaruga, 1999) and two of the most abundant plant species in this lagoon are $S$. californicus and $R$. maritima (Rodríguez-Gallego et al., 2010). Furthermore, Piccini et al. (2009) showed that CDOM photoalteration in Laguna de Rocha stimulates bacterioplankton activity and induces changes in bacterioplankton community composition in few hours, suggesting that photochemical processes are important for the availability of the organic matter derived from macrophytes. In the present study, we found an increase in bacterial biovolume and BCP after $5 \mathrm{~h}$ incubation in both treatments, implying that the measured bacterial production could be mostly due to the enriched bacterial populations. The development of bacterial morphotypes with cell sizes ca. 100 times larger than the rest of the community (for the case of SCD) suggests that these two populations of microorganisms exhibiting high growth rates rapidly incorporated the available organic carbon. We cannot rule out the possibility that the large filaments and rods not only developed because they reacted fast to the DOM amendment, but also because they are more resistant to photooxidative stress than the rest of the community. For example, photoproducts such as hydrogen peroxide are known to cause cell oxidative stress (Scully et al., 1996). It was outside the scope of this study, however, to measure the production of reactive oxygen species (ROS) during the experiment.

According to the similarity search, the big rod morphotypes were Acinetobacter-related bacteria closely related to the strain ADP1 (Vaneechoutte et al., 2006). It has been described that this strain has the capability to accumulate polyphosphate (PolyP) grains in their cytoplasm
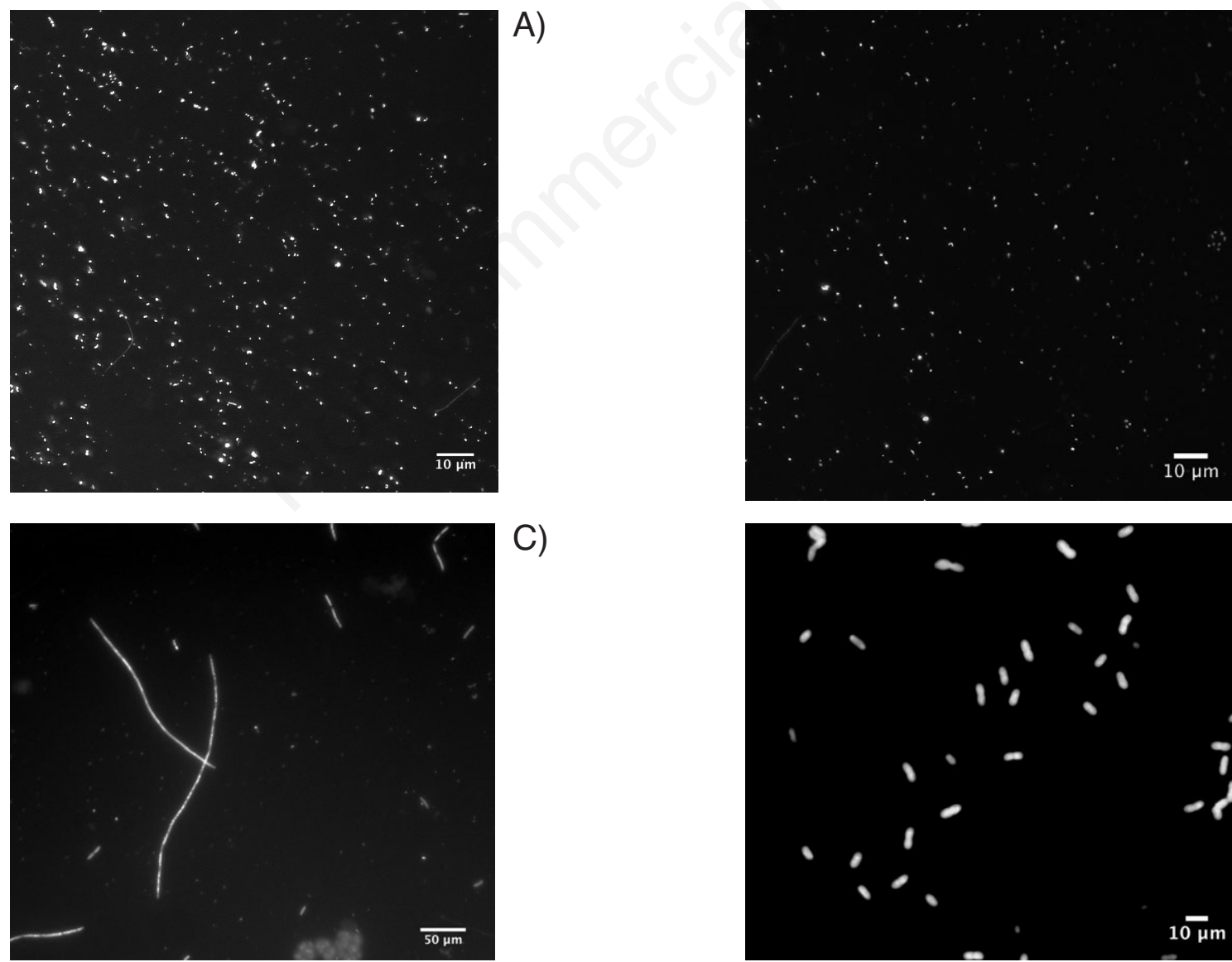

B)

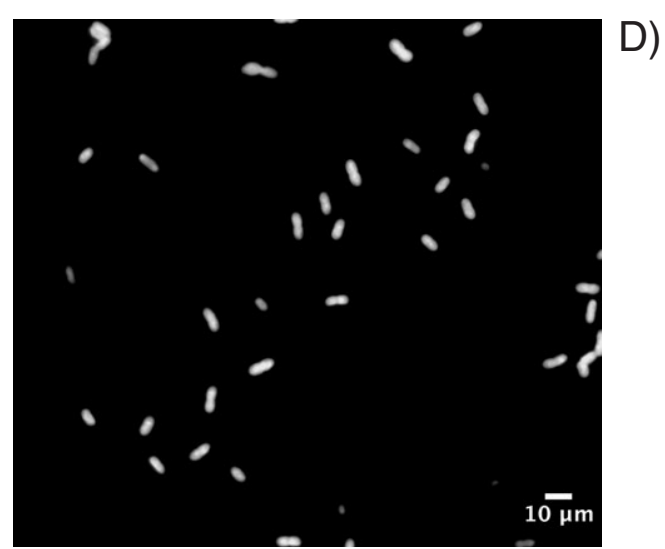

Fig. 2. Bacterial morphotypes found in A) S. californicus dissolved organic matter (SCD) treatment at T0 (DAPI stain) and B) R. maritima dissolved organic matter (RMD) treatment at T0 (DAPI stain). C) Filaments detected in SCD (DAPI stain) at 5 h; D) RMD hybridised with Acin0659A probe at $5 \mathrm{~h}$. 
under aerobic conditions and to use them later as a $\mathrm{P}$ source (Trelstad et al., 1999). Interestingly, microscopic examination of Acin0659A-hybridised cells showed the presence of yellow intracellular grains under UV excitation resembling PolyP (data not shown). The staining of bacterial PolyP granules by DAPI has been previously reported (Tijssen et al., 1982). In a study using Mediterranean seawater, Sebastián et al. (2012) found that some heterotrophic bacterial cells accumulate PolyP when incubated in phosphate-amended mesocosms. These authors proposed the existence of opportunistic bacteria (opportunitrophs) such as Gammaproteobacteria having high P requirements and able to accumulate phosphate inside the cell when this nutrient is available. The finding of fastgrowing, PolyP-accumulating cells of the Acinetobacter genus in our experiments suggest that plant-derived DOM extracts were rich in phosphorus and allowed for the enrichment of opportunistic bacterial populations.

An interesting finding of the present study was the development of large bacterial filaments in the DOM extracts. The formation of bacterial filaments has been also reported in several studies, mainly associated to heavy predation by heterotrophic nanoflagellates (Sommaruga and Psenner, 1995; Corno and Jürgens, 2006). Since in our experiment the presence of predators was reduced by dilution of the inoculums and not by filtration, it is possible that their presence would induce changes in bacterial morphology, in spite of the short incubation times $(5 \mathrm{~h})$. The identification of such filaments by cloning and sequencing of the $16 \mathrm{~S}$ rRNA genes revealed that the filaments belonged to Exiguobacterium genus. These bacteria have been found in diverse environments (Vishnivetskaya et al., 2000; Brambilla et al., 2001; Fruhling et al., 2002; Kim et al., 2005). This genus has been isolated from several habitats over a wide temperature range $\left(-12\right.$ to $\left.55^{\circ} \mathrm{C}\right)$ (Rodríguez and Tiedje, 2007 ) and it even survives to the exposure to UV-C radiation (Ponder et al., 2005). Some species of Exiguobacterium have also high levels of catalase and oxidase enzymes to minimise oxidative stress (Kim et al., 2005). This trait is probably important because ROS such as hydrogen peroxide are found among photoproducts from plant-derived DOM (Farjalla et al., 2001). Thus, the enrichment of an Exiguobacterium population with anti-ROS potential within a bacterial assemblage exposed to UVR would not be surprising. Further, it has been shown that natural UV radiation induces filamentation in lake bacterial assemblages (Corno et al., 2008; Modenutti et al. 2010). The exposure of bacteria to UV radiation could cause mutations in the fts $Z$ gene, which encodes for a protein involved in early stages of septum formation (Errington et al., 2003). For example, Feucht and Errington (2005) demonstrated that mutations of this gene induce filamentation in Bacillus subtilis. Interestingly, although the reported strains of Exiguobacterium are usually rods, the formation of filaments has been observed in response to temperatures as low as $-6^{\circ} \mathrm{C}$ with an increase in both cell length and width (Vishnivetskaya et al., 2007). Overall, the facts discussed above indicate that Exiguobacterium filaments detected in our study might be a combined response to solar radiation, increased DOM availability, presence of predators, and phenotypic

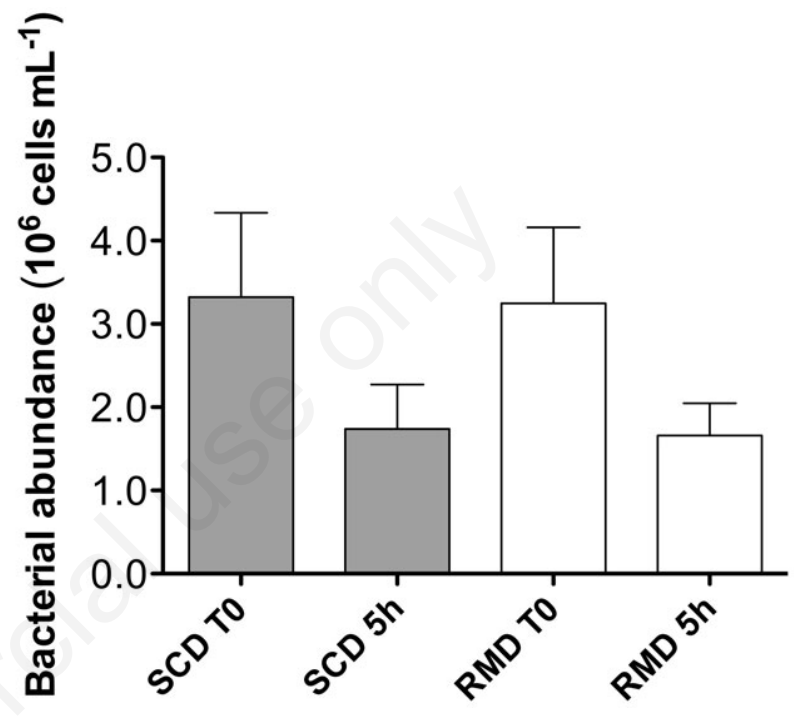

Fig. 3. Average bacterial abundance and standard deviations at the beginning (T0) and at after $5 \mathrm{~h}$ incubation in both plant treatments. Data do not include the abundance of large rods and filaments. $\mathrm{SCD}=$ dissolved organic matter from $S$. californicus; $\mathrm{RMD}=$ dissolved organic matter from $R$. maritima .

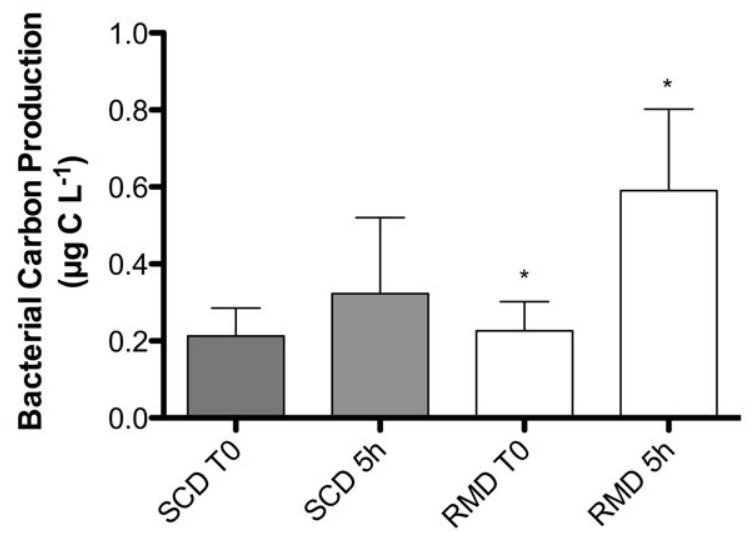

Fig. 4. Bacterial carbon production (BCP) measured in S. californicus dissolved organic matter (SCD) and R. maritima dissolved organic matter (RMD) treatments, at the beginning (T0) and after $5 \mathrm{~h}$ incubation. Asterisks indicate the treatments where significant differences were found between initial and final BCP. 
plasticity of the genus. However, owing to our experimental design, we cannot establish whether the appearance of large filamentous bacterial populations is a response naturally occurring in the environment or an artifact.

\section{CONCLUSIONS}

Overall, the results of the present study suggest that loading of DOM from plant origin might be a relevant source of carbon for bacterial populations in the freshwater zone of coastal lagoons. Further, due to the opportunistic-like behaviour of Acinetobacter and Exiguobacterium

A

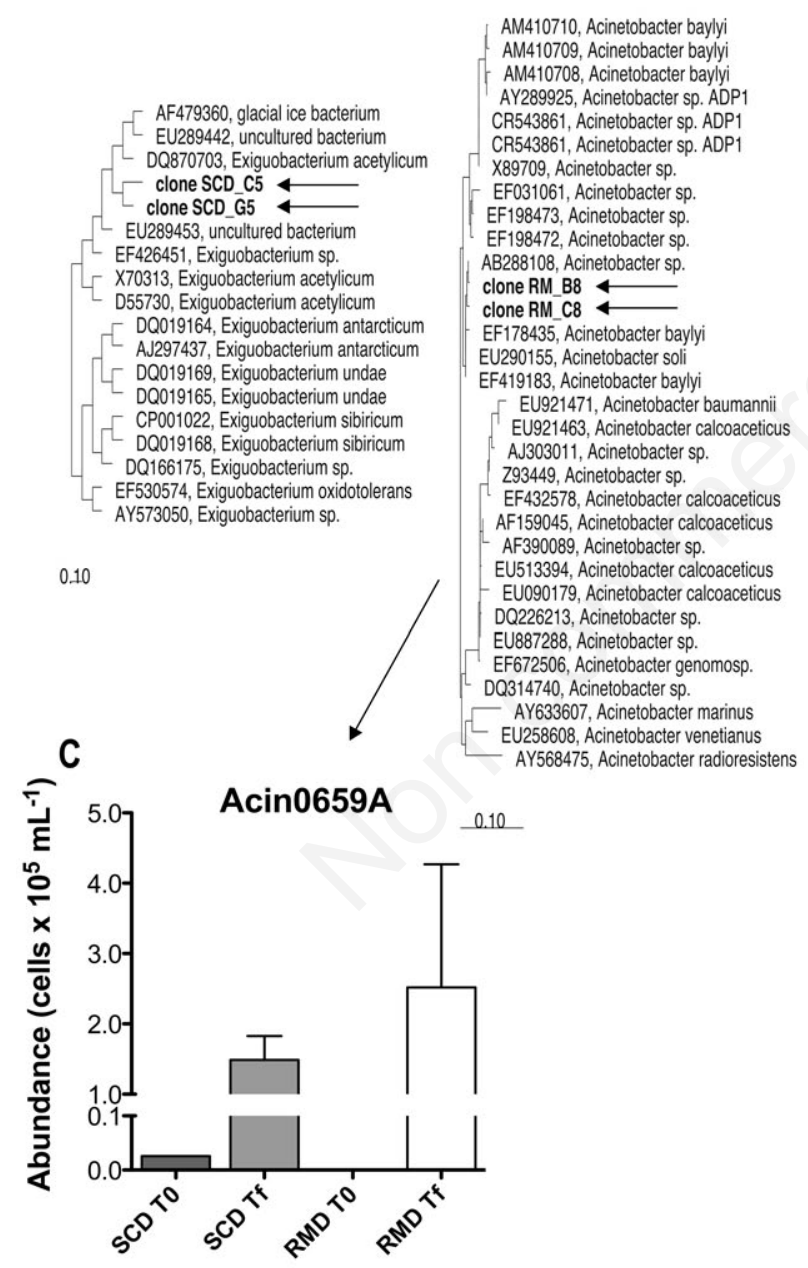

Fig. 5. Phylogenetic trees showing the affiliation of $16 \mathrm{~S}$ rRNA gene sequences obtained from clones G5 and C5 of S. californicus extract (A) and $\mathrm{B} 8$ and $\mathrm{C} 8$ of R. maritima extract (B). Only nearly complete sequences are depicted. Arrows indicate the position of sequenced clones. C) Abundance of Acin0659A-hybridised cells (by fluorescence in situ hybridisation) in both plant treatments at the beginning (T0) and the end (Tf) of incubations. Bar, $10 \%$ estimated sequence divergence. genera, they would play major role in the mineralisation of plant material after photochemical breakdown.

\section{ACKNOWLEDGMENTS}

We thank R. Amann from the Max Planck Institute for Marine Microbiology for hosting the first author in his lab. This work was supported by the International Foundation for Science (grant IFS A-2917/2), the programme for the development of sciences (PEDECIBA), and the Max Planck Society.

\section{REFERENCES}

Alonso C, Zeder M, Piccini C, Conde D, Pernthaler J, 2009. Ecophysiological differences of betaproteobacterial populations in two hydrochemically distinct compartments of a subtropical lagoon. Environ. Microbiol. 11:867-876.

Alonso C, Piccini C, Unrein F, Bertoglio F, Conde D, Pernthaler J, 2013. Environmental dynamics as a structuring factor for microbial carbon utilization in a subtropical coastal lagoon. Front. Microbiol. 4:14.

Altschul SF, Gish W, Miller W, Myers EW, Lipman DJ, 1990. Basic local alignment search tool. J. Mol. Biol. 215:403-410.

Benner R, 2002. Chemical composition and reactivity, p. 59-90. In: D. Hansell and C. Carlson (eds.), Biogeochemistry of marine dissolved organic matter. Academic Press.

Brambilla E, Hippe H, Hagelstein A, Tindall BJ, Stackebrandt E, 2001. 16S rDNA diversity of cultured and uncultured prokaryotes of a mat sample from Lake Fryxell, McMurdo Dry Valleys, Antartica. Extremophiles 5:23-33.

Conde D, Aubriot L, Sommaruga R, 2000. Changes in UV penetration associated with marine intrusions and freshwater discharge in a shallow coastal lagoon of the Southern Atlantic Ocean. Mar. Ecol.-Prog. Ser. 207:19-31.

Conde D, Sommaruga R, 1999. A review of the state of limnology in Uruguay, p. 1-31. In: J. Gopal and R. Wetzel (eds.), Limnology in developing countries. International Scientific Publ.

Corno G, Caravati E, Callieri C, Bertoni R, 2008. Effects of predation pressure on bacterial abundance, diversity, and sizestructure distribution in an oligotrophic system. J. Limnol. 67:107-119.

Corno G, Jürgens K, 2006. Direct and indirect effects of protist predation on population size structure of a bacterial strain with high phenotypic plasticity. Appl. Environ. Microb. 72:78-86.

Cottrell MT, Kirchman DL, 2000. Natural assemblages of marine proteobacteria and members of the Cytophaga-Flavobacter cluster consuming low- and high- molecular weight dissolved organic matter. Appl. Environ. Microb. 66:1692-1697.

Crump BC, Kling GW, Bahr M, Hobbie JE, 2003. Bacterioplankton community shifts in an arctic lake correlate with seasonal changes in organic matter source. Appl. Environ. Microb. 69:2253-2268.

De Haan H, 1993. Solar UV-light penetration and photodegradation of humic substances in peaty lake water. Limnol. Oceanogr. 38:1072-1076.

Del Giorgio PA, Davis J, 2003. Patterns in dissolved organic matter lability and comsumption across aquatic ecosystems, p. 399-424. In: S.E.G. Findlay and R.L. Sinsabaugh (eds.), 
Aquatic ecosystems: interactivity of dissolved organic matter. Academic Press.

Elifantz H, Malmstrom RR, Cottrell MT, Kirchman DL, 2005. Assimilation of polysaccharides and glucose by major bacterial groups in the Delaware Estuary. Appl. Environ. Microb. 71:7799-7805.

Errington J, Daniel RA, Scheffers DJ, 2003. Cytokinesis in bacteria. Microbiol. Mol. Biol. R. 67:52-65.

Farjalla VF, Anesio AM, Bertilsson S, Granéli W, 2001. Photochemical reactivity of aquatic macrophyte leachates: abiotic transformations and bacterial response. Aquat. Microb. Ecol. 24:187-195.

Feucht A, Errington J, 2005. ftsZ mutations affecting cell division frequency, placement and morphology in Bacillus subtilis. Microbiology 151:2053-2064.

Fruhling A, Schumann P, Hippe H, Straubler B, Stackebrandt H, 2002. Exiguobacterium undae sp. nov. and Exiguobacterium antarcticum sp. nov. Int. J. Syst. Evol. Micr. 52:1171-1176.

Helms JR, Stubbins A, Ritchie JD, Minor EC, Kieber DJ, Mopper K, 2008. Absorption spectral slopes and slope ratios as indicators of molecular weight, source, and photobleaching of chromophoric dissolved organic matter. Limnol. Oceanogr. 53:955-969.

Kim IG, Lee MH, Jung SY, Song JJ, Oh TK, Yoon JH, 2005. Exiguobacterium aestuarii sp. nov. and Exiguobacterium marinum sp. nov., isolated from a tidal flat of the Yellow Sea in Korea. Int. J. Syst. Evol. Micr. 55:885-889.

Kirchman DL, Yu LY, Fuchs BM, Amann R, 2001. Structure of bacterial communities in aquatic systems as revealed by filter PCR. Aquat. Microb. Ecol. 26:13-22.

Kirk JTO, 1994. Light and photosynthesis in aquatic ecosystems. Cambridge University Press, New York: 662 pp.

Ludwig W, Strunk O, Westram R, Richter L, Meier H, Yadhukumar, Buchner A, Lai T, Steppi S, Jobb G, Förster W, Brettske I, Gerber S, Ginhart AW, Gross O, Grumann S, Hermann S, Jost R, König A, Liss T, Lüssmann R, May M, Nonhoff B, Reichel B, Strehlow R, Stamatakis A, Stuckmann N, Vilbig A, Lenke M, Ludwig T, Bode A, Schleifer KH, 2004. ARB: a software environment for sequence data. Nucleic Acids Res. 32:1363-1371.

Mann CJ, Wetzel RG. 1996. Loading and utilization of dissolved organic carbon from emergent macrophytes. Aquat. Bot. 53:61-72.

Massana R, Gasol JM, Bjørnsen PK, Black-Burn N, Hagstrom A, Hietanen S, Hygum BH, Kuparinen J, Pedros-Alio C, 1997. Measurement of bacterial size via image analysis of epifluorescence preparations: description of an inexpensive system and solutions to some of the most common problems. Sci. Mar. 61:397-407.

McKnight DM, Andrews ED, Spulding SA, Aiken GR, 1994. Aquatic fulvic acids in algal-rich antarctic ponds. Limnol. Oceanogr. 39:1972-1979.

McKnight DM, Boyer EW, Westerhoff PK, Doran PT, Kulbe T, Anderson DT, 2001. Spectrofluorometric characterization of dissolved organic matter for indication of precursor organic material and aromaticity. Limnol. Oceanogr. 46:38-48.

Meier H, Amann R, Ludwig W, Schleifer K, 1999. Specific oligonucleotide probes for in situ detection of a major group of Gram-positive bacteria with low DNA G+C content. Syst. Appl. Microbiol. 22:186-196.
Modenutti B, Balseiro E, Corno G, Callieri C, Bertoni R, Caravati $\mathrm{E}, 2010$. Ultraviolet radiation induces filamentation in bacterial assemblages from North Andean Patagonian lakes. Photochem. Photobiol. 86:871-881.

Muyzer G, Teske A, Wirsen CO, Jannasch HW, 1995. Phylogenetic relationship of Thiomicrospira species and their identification in deep-sea hydrothermal vent samples by denaturing gradient gel electrophoresis of $16 \mathrm{~S}$ rDNA fragments. Arch. Microbiol. 164:165-172.

Nedoma J, Vrba J, Hanzl T, Nedbalova L, 2001. Quantification of pelagic filamentous microorganisms in aquatic environments using the line-intercept method. FEMS Microbiol. Ecol. 38:81-85.

Oerther DB, Danalewich J, Dulekurgen E, Leveque E, Freedman DL, Raskin L, 1998. Bioaugmentation of sequencing batch reactors for biological phosphorous removal: comparative rRNA sequence analysis and hybridization with oligonucleotide probes. Wa. Sci. Technol. 37:469-473.

Osburn CL, Zagarese H, Morris D, Hargreaves B, Cravero W, 2001. Calculation of spectral weighting functions for the solar photobleaching of chromophoric dissolved organic matter in temperate lakes. Limnol. Oceanogr. 46:1455-1467.

Pernthaler A, Pernthaler J, Amann R, 2004. Sensitive multicolour fluorescence in situ hybridization for the identification of environmental organisms, p. 711-726. In: G.A. Kowalchuk, F.J. De Bruijn, I.M. Head, A.D.L. Akkermans and J.D. van Elsas (eds.), Molecular microbial ecology manual. Kluwer Academic Publ.

Piccini C, Conde D, Pernthaler J, Sommaruga R, 2009. Alteration of chromophoric dissolved organic matter by solar UV radiation causes rapid changes in bacterial community composition. Photochem. Photobio. Sci. 8:1321-1328.

Ponder MA, Gilmour SJ, Bergholz PW, Mindock CA, Hollingsworth R, Thomashow MF, Tiedje JM, 2005. Characterization of potential stress responses in ancient Siberian permafrost psychroactive bacteria. FEMS Microbiol. Ecol. 53:103-115.

Porter KG, Feig YS, 1980. The use of DAPI for identifying and counting aquatic microflora. Limnol. Oceanogr. 25:943-948.

Rodríguez DF, Tiedje JM, 2007. Multi-locus real-time PCR for quantitation of bacteria in the environment reveals Exiguobacterium to be prevalent in permafrost. FEMS Microbiol. Ecol. 59:489-499.

Rodríguez-Gallego L, Meerhoff E, Clemente JM, Conde D, 2010. Can ephemeral proliferations of submerged macrophytes influence zoobenthos and water quality in coastal lagoons? Hydrobiologia 646:253-269.

Scully NM, Lean DRS, McQueen DJ, Cooper WJ, 1996. Hydrogen peroxide formation: the interaction of ultraviolet radiation and dissolved organic carbon in lake waters along a $43-75^{\circ} \mathrm{N}$ gradient. Limnol. Oceanogr. 41:540-548.

Sebastián M, Pitta P, Gonzalez JM, Thingstad TF, Gasol JM, 2012. Bacterioplankton groups involved in the uptake of phosphate and dissolved organic phosphorus in a mesocosm experiment with P-starved Mediterranean waters. Environ. Microbiol. 14:2334-2347.

Simon M, Azam F, 1989. Protein content and protein synthesis rates of planktonic marine bacteria. Mar. Ecol.-Prog. Ser. 51:201-213.

Sommaruga R, Psenner R, 1995. Permanent presence of gra- 
zing-resistant bacteria in a hypertrophic lake. Appl. Environ. Microb. 61:3457-3459.

Tijssen JP, Beekes HW, Van SJ, 1982. Localization of polyphosphates in Saccharomyces fragilis, as revealed by 4', 6-diamidino-2-phenylindole fluorescence. Biochim. Biophys. Acta 721:394-398.

Trelstad PL, Purdhani P, Geidorfer W, Hillen W, Keasling JD, 1999. Polyphosphate kinase of Acinetobacter sp. strain ADP1: purification and characterization of the enzyme and its role during changes in extracellular phosphate levels. Appl. Environ. Microb. 65:3780-3786.

Vaneechoutte M, Young DM, Ornston LN, De Baere T, Nemec A, Van Der Reijden T, Carr E, Tjernberg I, Dijkshoorn L, 2006. Naturally transformable Acinetobacter sp. strain ADP1 belongs to the newly described species Acinetobacter baylyi. Appl. Environ. Microb. 72:932-936.

Vishnivetskaya TA, Kathariou S, McGrath J, Gilichinsky D, Tiedje JM, 2000. Low-temperature recovery strategies for the isolation of bacteria from ancient permafrost sediments. Extremophiles 4:165-173.

Vishnivetskaya TA, Siletzky R, Jefferies N, Tiedje JM, Kathariou S, 2007. Effect of low temperature and culture media on the growth and freeze-thawing tolerance of Exiguobacterium strains. Cryobiology 54:234-240.

Wetzel RG, 1992. Gradient-dominated ecosystems: sources and regulatory functions of dissolved organic matter in freshwater ecosystems. Hydrobiologia 229:181-198.

Wetzel RG, 2003. Solar radiation as an ecosystem modulator, p. 3-18. In: E.W. Helbling and H. Zagarese (eds.), UV Effects in aquatic organisms and ecosystems. RSC Publ. 